\title{
THE EVOLUTION OF THE AISNE FLOODPLAIN (ARDENNE, BELGIUM) DURING THE LAST CENTURIES STUDIED WITH THE MICROSLAG DATING METHOD
}

DOI: https://doi.org/10.18509/AGB.2021.16
UDC: $551.435 .2(493)$

\author{
Geoffrey Houbrechts ${ }^{1}$, Alexandre Peeters ${ }^{1}$, François Petit ${ }^{1}$, \\ Tomasz Kalicki², Pawel Przepióra ${ }^{2}$
}

\author{
${ }^{1}$ University of Liège, UR Spheres, Fluvial Geomorphology and Hydrology Research Center, Belgium \\ ${ }^{2}$ Institute of Geography and Environmental Sciences, Jan Kochanowski University in Kielce, Poland
}

corresponding author: pawelprzepiora1988@gmail.com

submitted: 18.05 .2020
accepted: 12.08 .2020
published: 25.10 .2020

\begin{abstract}
In the Ardenne massif (south Belgium) many traces of metallurgical activity are present. An intensive development of iron industry took place from the Middle Ages until the middle of the 19th century. Many small upland rivers powered water wheel of forges and blast furnaces [1]. Among these rivers, the geomorphic evolution of the upstream part of the Aisne River was studied. By means of microslag evaluation [2], topographic surveys and sedimentological analyses, the floodplain history may be reconstructed, fine floodplain sedimentation and channel changes are identified. Analyses of slag concentrations allowed us to reconstruct the evolution of the floodplain topography over the last centuries. In the upstream part of the Aisne catchment, the floodplain aggradation is less than $17 \mathrm{~cm}$ since the 15th century, which corresponds to an aggradation rate lower than $3 \mathrm{~cm} /$ century. Such rate is very low compared to other rivers [2] and to the lowest part of the Aisne catchment [3]. Moreover, our results show that the thickness of fine alluvia on the low terrace is approximately 50 $\mathrm{cm}$ and the incision of the riverbed is of the same order (between 46 and $77 \mathrm{~cm}$ ). It therefore appears that the floodplain level has reached an equilibrium before the establishment of the ironworks in the valley (in the 15th century) and the sedimentation does not appear to have continued since then.
\end{abstract}

Keywords: fluvial geomorphology, floodplain, slag, Ardenne, Aisne River

\section{INTRODUCTION}

In recent years, issues related to the activities of the historical metallurgical industry and its impacts on the small European river valleys morphology are raised in many works [2], [3], [4], [5], [6]. The Aisne valley is one of these regions where slag analyses show interesting results. The Aisne River, that belongs to the Meuse catchment, is a small meandering river (catchment area: $190 \mathrm{~km}^{2}$ ). This area (southern part of Belgium, Fig. 1) is located at the western part of the Rhenish shield that corresponds to the Ardenne Massif (Hercinian Massif). The Aisne River is characterized by a gravelbed (D50 of riffles : $70-100 \mathrm{~mm}$ ), a single channel and a specific stream power at bankfull stage comprised between 72 and $111 \mathrm{~W} / \mathrm{m}^{2}$. In the Aisne catchment, many traces left by metallurgical activity may be observed. Intensive development of metallurgy took place from the Middle Ages (approximately 1400 AD) until the beginning of the 17th century [1] [7] (Fig. 2). Moreover, the Aisne River and its tributaries powered many water wheels of mills and sawmills. Most of these industrial facilities have not survived to nowadays, when technological changes led to the liquidation of outdated forges. The Aisne floodplain in the upstream part of the catchment does not exceed 200 $\mathrm{m}$ in width. At the location of the study site, the floodplain is occupied by grasslands, while nearby steep slopes are covered by forest (Fig. 3). At the location of the study reach a palaeochannel and an alluvial fan are clearly visible on the LIDAR Hillshade DEM (Fig. 4A). Upstream of the study cross profile, several centimeters slag fragments creating visible heap was found (Fig. 5). 


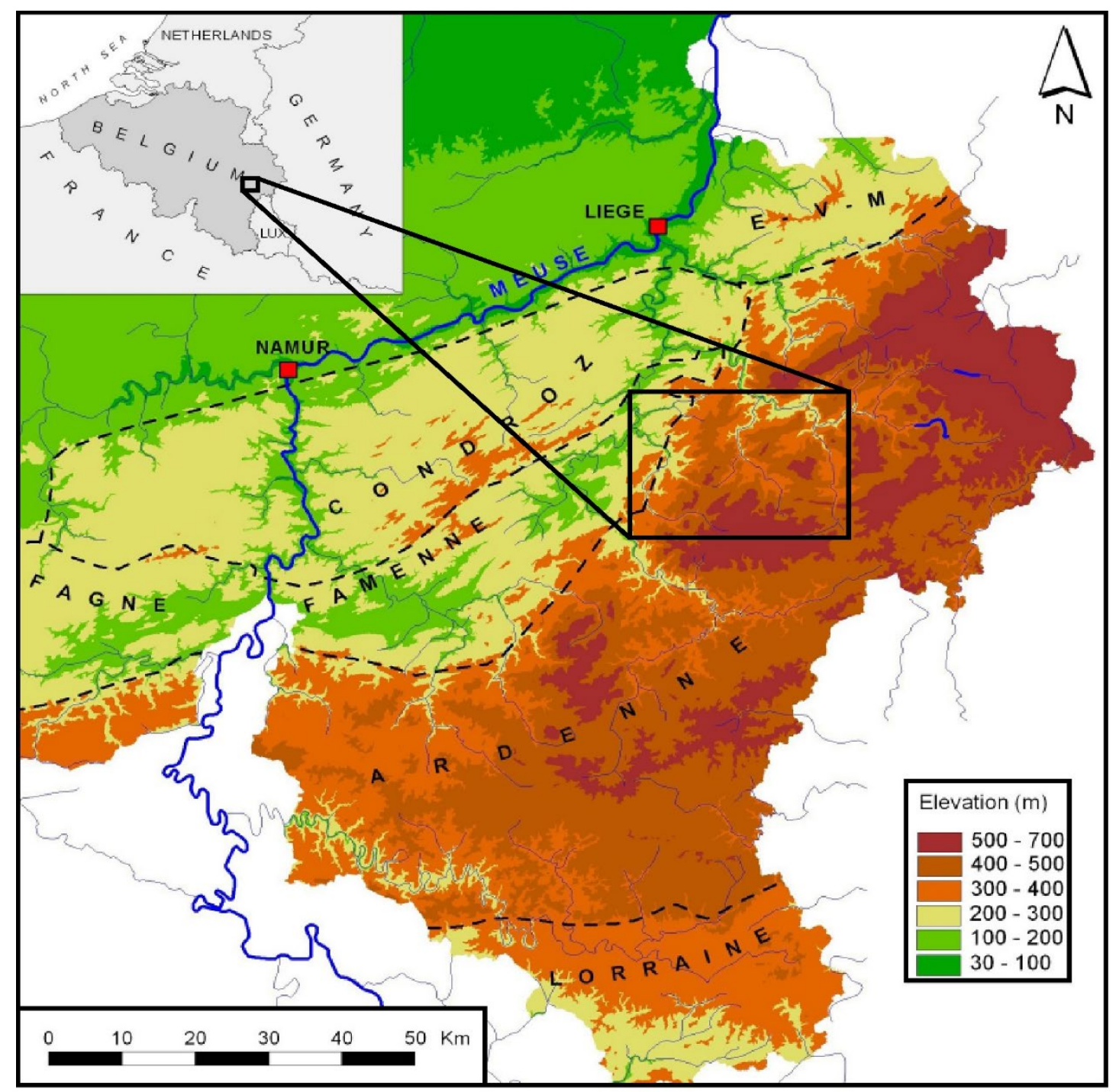

Figure 1. Location of the study area.

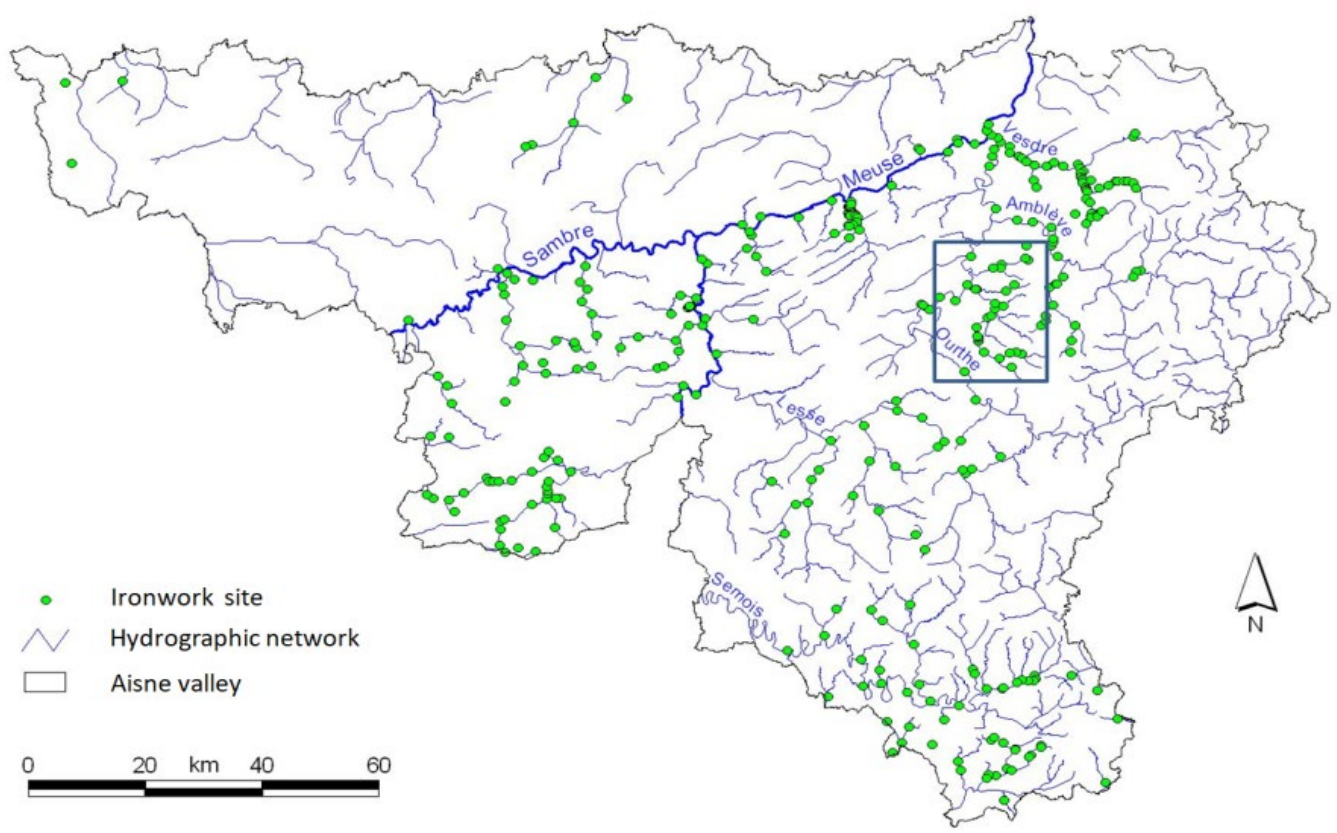

Figure 2. Location of study area in the map of past metallurgical sites (1350-1850) in Wallonia (South part of Belgium) 


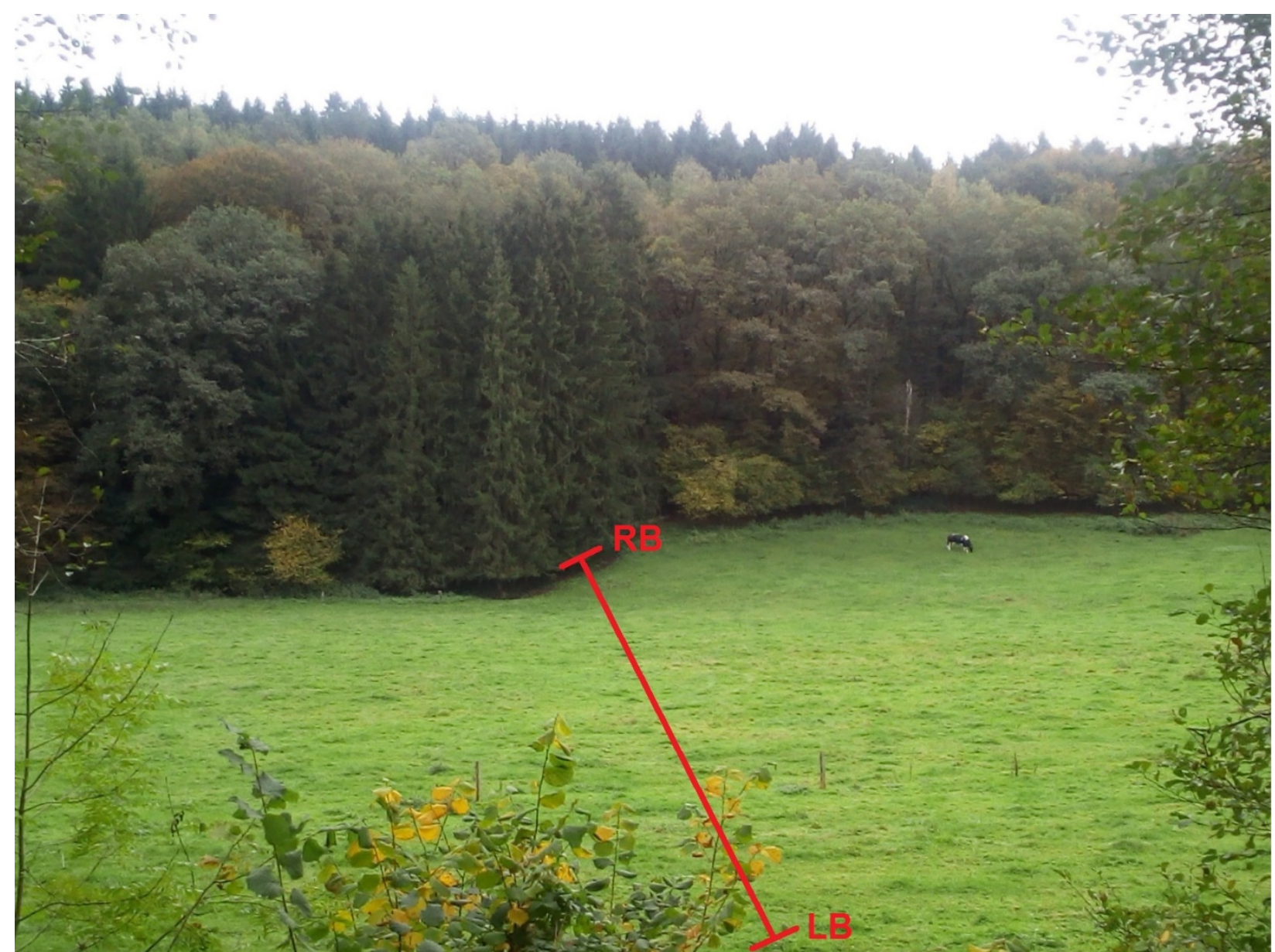

Figure 3. Cross section Wérichet in the Aisne river floodplain.

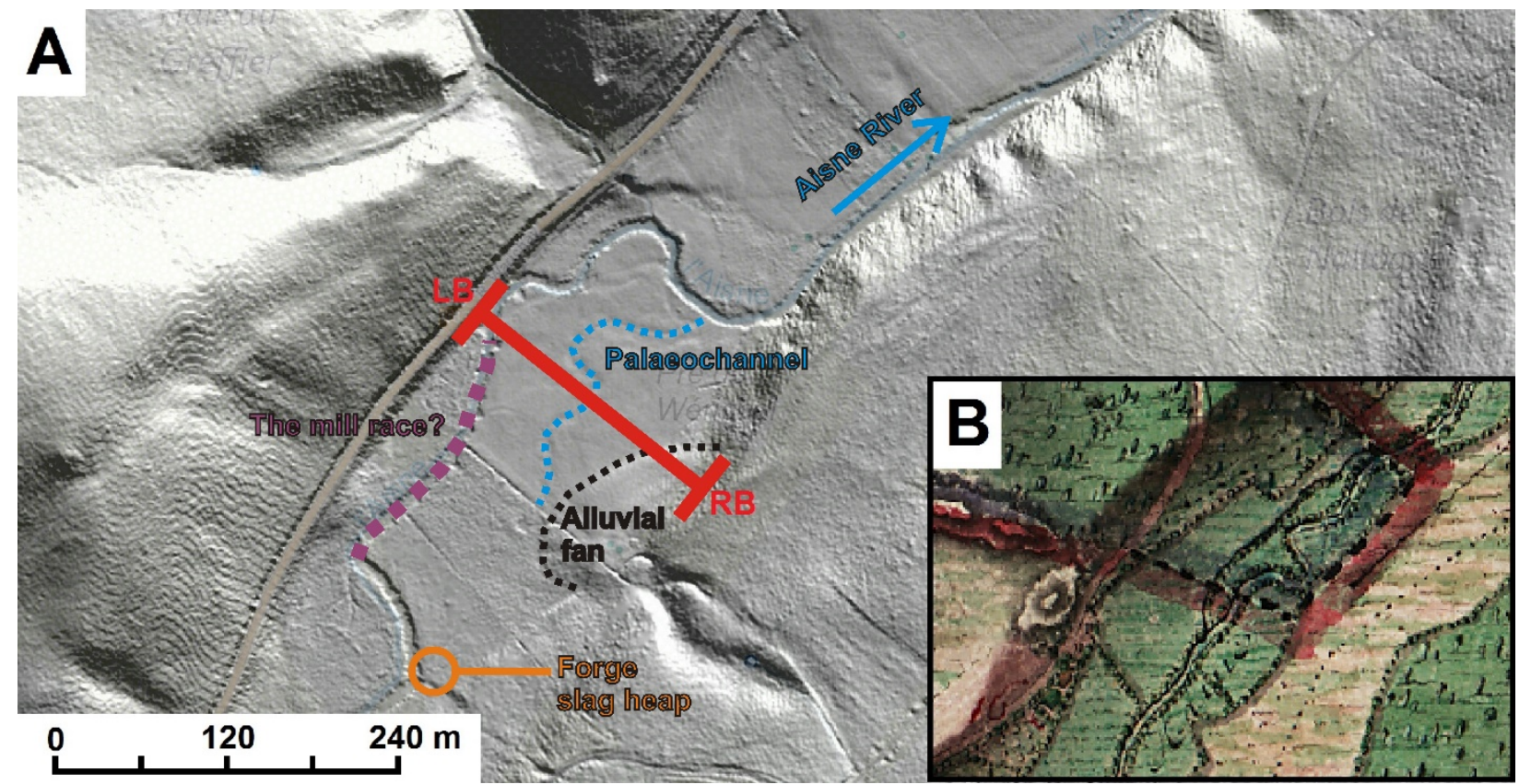

Figure 4. Cross section Wérichet in the Aisne river floodplain on DEM

(A) and same area on Ferraris map from 1775 (B) [8]. 


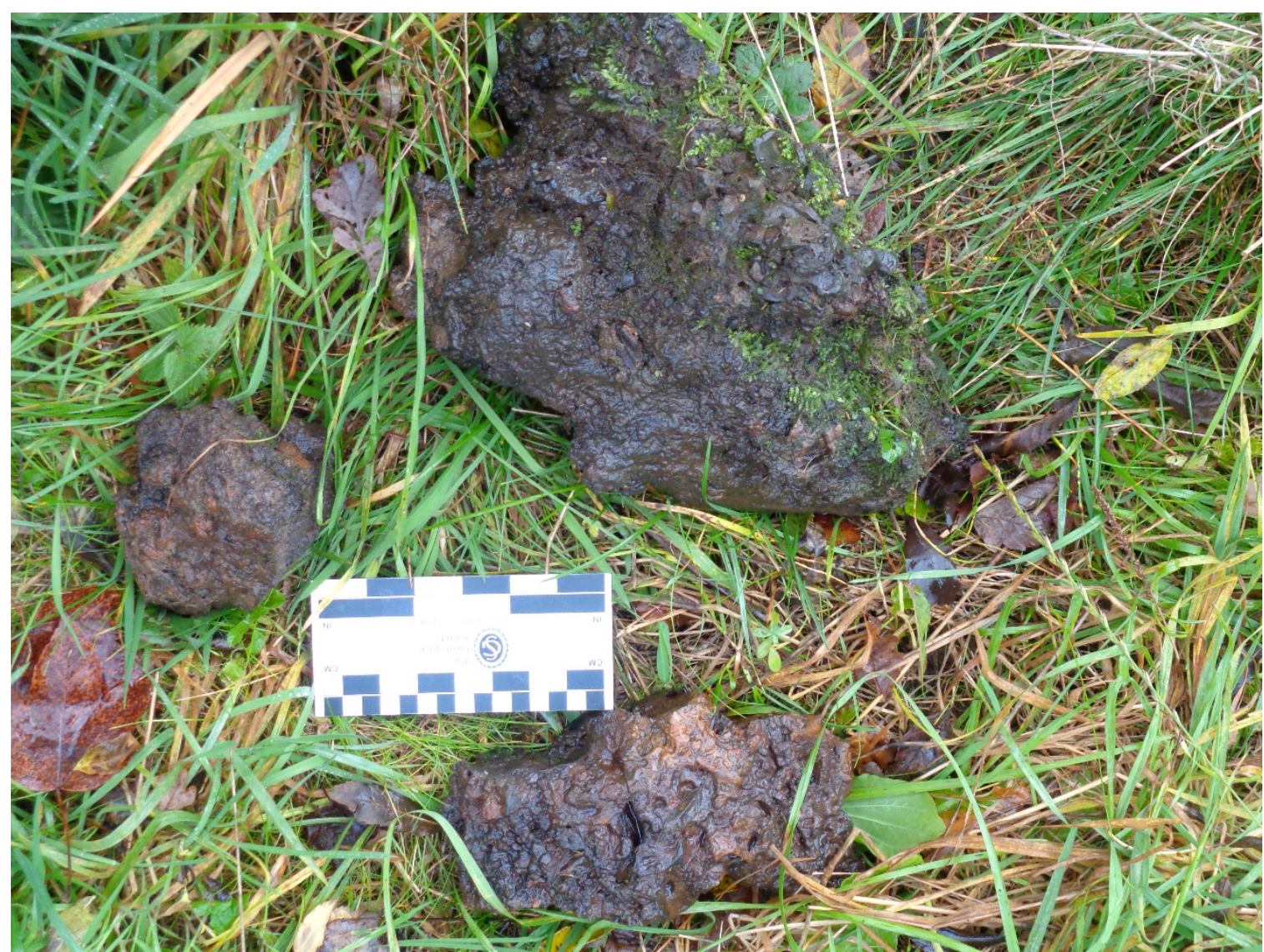

Figure 5. Large slag fragments from slag heap near Aisne river bed.

\section{AIM OF THE STUDY AND METHODS}

The aim of the study is to reconstruct the floodplain evolution of the Aisne River by means of anthropogenic tracer (microslag) accumulated in alluvia downstream of the ancient forge of Wérichet (WER). In this case, the field prospection was carried out using historical data (old maps from the 18 th and 19th centuries) to locate potential areas with metallurgical activity remains. The $160 \mathrm{~m}$ cross section in floodplain was selected because of the presence of a palaeochannel and the micro-

\section{RESULTS}

The topography of the cross section (Fig. 6) shows an upper level (WER4) that can be interpreted as a low terrace and also emphases a palaeochannel and a mound (WER2) that could correspond to a past natural levee or to an old dredge spoil mound.

The slag concentration analyses show the occurrence of slag on both sides of the palaeochannel: in samples of boreholes WER 3 and WER 1, but in the latter with a lower concentration (Fig. 6). It is also necessary to consider that only $0.5 \%$ of slag are found at the base of borehole WER3. This concentration is not significant and could result from bioturbation or contamination during sampling. The largest amount of metallurgical residues is found in borehole WER 3 between 20 and $33 \mathrm{~cm}$ depth (approximately 25\% of the slag in the coarsest grainsize classes). Slag topography (Fig. 4A). Moreover, old maps indicate that this paleochannel could correspond to the main channel of the 18th century and that the present-day channel could be situated in the 18th century mill race (Fig. 4B). Samples from 5 boreholes were collected, washed and sieved in laboratory to analyze vitreous slag concentrations [9]. Unfortunately, the palaeochannel was too humid and swampy, which made it impossible to conduct sampling in center of the palaeochannel.

particles present on both sides of the palaeochannel confirm that this part of the floodplain was reworked by the lateral mobility of the channel. Only some slag fragments were found in the sample taken in surface in borehole WER5. Moreover, analyses show that alluvia in boreholes 4, 2 and 5 are older than the inception of the metallurgy.

The gravel layer in WER 2 is at the same elevation as the current channel bed. The gravel layer in WER 4 is perched $77 \mathrm{~cm}$ above the current channel bed. The gravel layer in WER 1, 3 and 5 are at the same elevation but are below the current water level for low flow conditions (this water level can be interpreted as the level the highest riffles). The incision between the top of the gravel layer under the low terrace (borehole WER4) and the level of WER 1,3 and 5 is $49 \mathrm{~cm}$. Another important 
information is the thickness of fine grainsize alluvia in the Aisne valley bottom. The thickest deposit is situated at the location of borehole $2(123 \mathrm{~cm})$. But as explained above, the upper deposits could correspond to a past natural levee or an old dredge spoil mound.

It should be noted that the thickness of fine alluvia was already important on the low terrace $(57 \mathrm{~cm}$ in borehole 4) and was about $50 \mathrm{~cm}$ in WER5 at the inception of metallurgy. The actual thickness of fine alluvia in the floodplain is $59 \mathrm{~cm}$ (WER5). That means that the floodplain aggradation is less than $17 \mathrm{~cm}$ since the inception of the metallurgy and corresponds to an accumulation rate of less than 3 $\mathrm{cm} /$ century. This value is very low compared to other observations in the Ardenne massif [3], but also to the downstream part of the Aisne valley were $1 \mathrm{~m}$ of accumulation was observed during the same period [9]. Such differences are still not well explained because they are linked to many factors, such as the distance to past cultivation areas, the degree of woodland clearance, flow velocities during floods and the incision of the riverbed during recent centuries, reducing the frequency of inundation and, therefore, the sedimentation in floodplains.

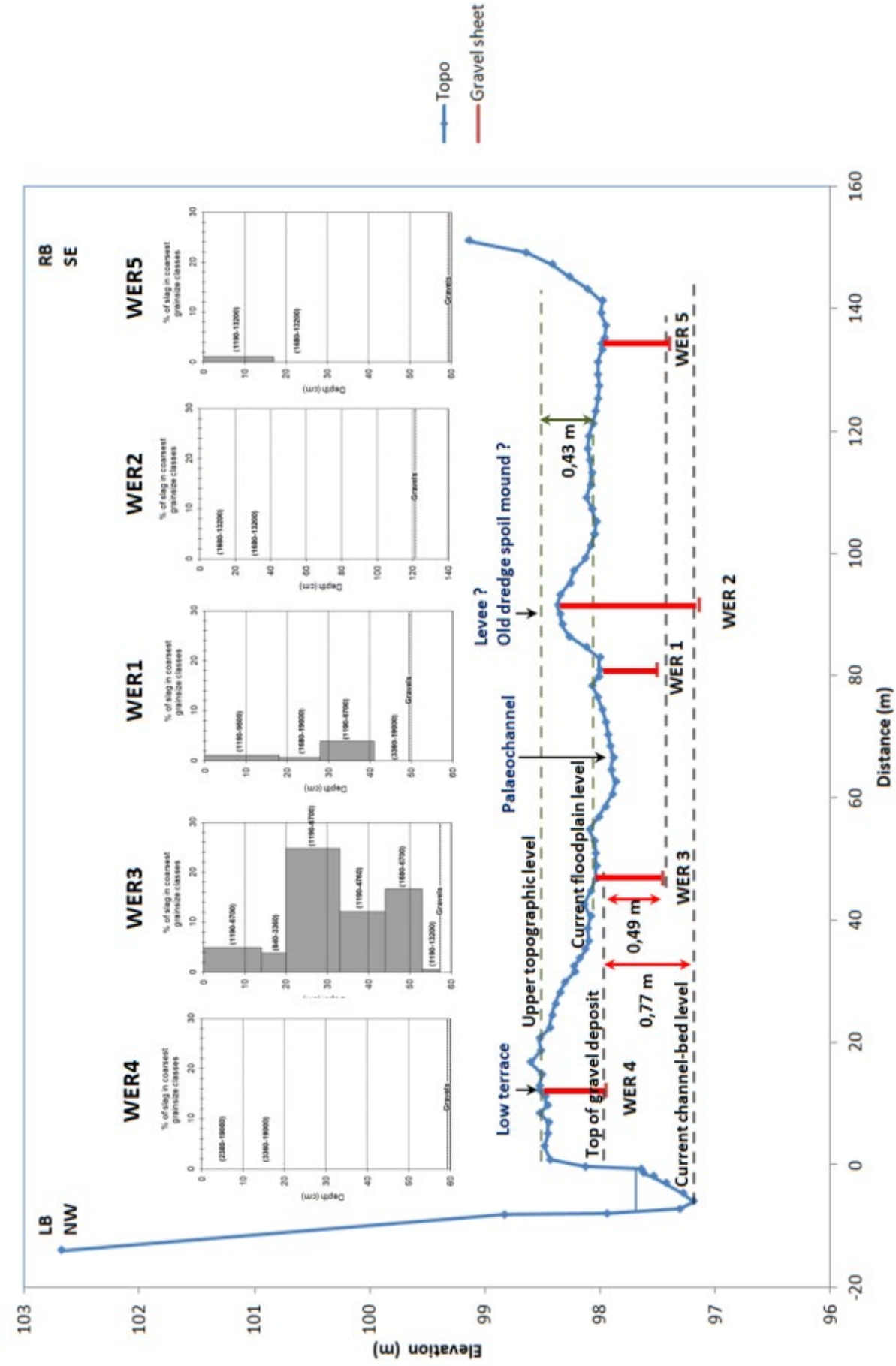

Figure 6. Cross section Wérichet - first results from the boreholes samples and slag concentrations in alluvia (coarsest grain size classes) 
Moreover, the relative stability of the floodplain level since the 15 th century corresponds probably to an equilibrium stage. Surprisingly, the same thickness of fine sediment is observed on the low terrace when the river was flowing $77 \mathrm{~cm}$ above the

\section{CONCLUSION}

The study of the upstream part of the Aisne valley confirm that microslag particles are present in some deposits of the floodplain. The old maps indicate channel changes since the 18th century. Slag particles present on both sides of the palaeochannel confirm that this part of the floodplain has been reworked by the lateral mobility of the channel. A small thickness of alluvia with slag, in a borehole present-day bed channel level. It therefore appears that the metallurgical activity and its associated deforestation have not had a significant impact on the sedimentation of the floodplain in this part of the Aisne valley.

near the slope (WER5) away from the river, indicates a low sedimentation rate $(3 \mathrm{~cm} /$ century). The relative stability of the floodplain level since the 15 th century correspond probably to an equilibrium stage. More detailed results will be obtained by further research, which will focus on the palaeochannel.

\section{REFERENCES}

[1] Houbrechts G. \& Petit F., Evolution des techniques sidérurgiques pré-industrielles et aperçu des critères de localisation de la métallurgie en "Terre de Durbuy", Bulletin du cercle historique de Durbuy, 89, pp. 2-29, 2004.

[2] Houbrechts G., Petit F., Notebaert B., Kalicki T. \& Denis A.-C., Microslag as a stratigraphic tracer to quantify floodplain processes (Lienne catchment, Belgium), Geomorphology, in press, 2020.

[3] Houbrechts G., Utilisation des macroscories et des microscories en dynamique fluviale: application aux rivières du massif ardennais. PhD thesis, Université de Liège, pp 328, 2005.

[4] Rutkiewicz P. \& Gawior D., Górnictwo kruszcowe jako czynnik kształtujący krajobraz w rezerwacie Segiet (Wyżyna Śląska) na podstawie danych lidarowych [in:] R. Machowski \& M.A. Rzętała (ed.) Z badań nad wpływem antropopresji na środowisko, UŚ, Sosnowiec, Poland, vol. 16, pp 80-86, 2015.

[5] Przepióra P., Houbrechts G., Kalicki T., Peeters A., Pabian G., Kusztal P., Nowak E. \& Rutkiewicz P., Post-mining relief and its present-day changes in the European Hercinian Mountains - cases study from Ardennes and Holy Cross Mountains, 25th Quaternary Conference, Brno, Czech Republic, pp 55, 2019.

[6] Houbrechts G., Levecq Y., Vanderheyden V. \& Petit F., Long-term bedload mobility in gravel-bed rivers using iron slag as a tracer. Geomorphology, 126, pp. 233-244, 2011.

[7] Pirotte F., L'industrie métallurgique de la Terre de Durbuy de 1480 à 1625 . Ses rapports avec la métallurgie liégeoise. Bulletin de l'Institut archéologique liégeois, 79, pp 145-210, 1967.

[8] geoportail.wallonie.be.

[9] Houbrechts G., Des scories dans les alluvions du bassin de l'Ourthe: origine et utilisation en géomorphologie, 2020. 